\title{
Electrochemical immunosensors using electrodeposited gold nanostructures for detecting the $S$ proteins from SARS-CoV and SARS-CoV-2
}

\author{
Laís Canniatti Brazaca ${ }^{1,2}$. Amanda Hikari Imamura ${ }^{1,2}$ - Nathalia Oezau Gomes ${ }^{1}$ Mariana Bortholazzi Almeida ${ }^{1,2}$. \\ Desirée Tamara Scheidt ${ }^{1,2}$. Paulo A. Raymundo-Pereira ${ }^{3}$. Osvaldo N. Oliveira $\mathrm{Jr}^{3}$ • Bruno Campos Janegitz ${ }^{4}$. \\ Sergio Antonio Spinola Machado ${ }^{1}$ Emanuel Carrilho ${ }^{1,2}$
}

Received: 21 December 2021 / Revised: 29 January 2022 / Accepted: 1 February 2022 / Published online: 15 February 2022

(c) Springer-Verlag GmbH Germany, part of Springer Nature 2022

\begin{abstract}
This paper reports the development of a low-cost (<US\$ 0.03 per device) immunosensor based on gold-modified screenprinted carbon electrodes (SPCEs). As a proof of concept, the immunosensor was tested for a fast and sensitive determination of S proteins from both SARS-CoV and SARS-CoV-2, by a single disposable device. Gold nanoparticles were electrochemically deposited via direct reduction of gold ions on the electrode using amperometry. Capture antibodies from spike (S) protein were covalently immobilized on carboxylic groups of self-assembled monolayers (SAM) of mercaptoacetic acid (MAA) attached to the gold nanoparticles. Label-free detection of S proteins from both SARS-CoV and SARS-CoV-2 was performed with electrochemical impedance spectroscopy (EIS). The immunosensor fabricated with $9 \mathrm{~s}$ gold deposition had a high performance in terms of selectivity, sensitivity, and low limit of detection (LOD) (3.16 pmol L $\mathrm{L}^{-1}$ ), thus permitting the direct determination of the target proteins in spiked saliva samples. The complete analysis can be carried out within 35 min using a simple one-step assay protocol with small sample volumes $(10 \mu \mathrm{L})$. With such features, the immunoplatform presented here can be deployed for mass testing in point-of-care settings.
\end{abstract}

Keywords SARS-CoV $\cdot$ SARS-CoV-2 $\cdot \mathrm{S}$ protein $\cdot$ Diagnosis $\cdot$ Immunosensor $\cdot$ Gold nanoparticles

\section{Introduction}

Published in the topical collection featuring Promising Early-Career (Bio)Analytical Researchers with guest editors Antje J. Baeumner, María C. Moreno-Bondi, Sabine Szunerits, and Qiuquan Wang.

Laís Canniatti Brazaca

lais.brazaca@usp.br

$\bowtie$ Emanuel Carrilho

emanuel@iqsc.usp.br

1 Present Address: Instituto de Química de São Carlos, Universidade de São Paulo, São Carlos, SP 13566-590, Brazil

2 Instituto Nacional de Ciência e Tecnologia de Bioanalítica-INCTBio, Campinas, SP 13083-970, Brazil

3 Instituto de Física de São Carlos, Universidade de São Paulo, São Carlos, SP 13566-590, Brazil

4 Departamento de Ciências da Natureza, Matemática e Educação, Universidade Federal de São Carlos, Araras, SP 13600-970, Brazil
The crisis with COVID-19 has highlighted the need for analytical devices to monitor and detect high-incident diseases caused by viruses and other pathogens with rapid propagation and mutations. Low-cost, portable analytical sensors [1-3] are perhaps the only alternative for the diagnosis of such infections as the one caused by the coronavirus (SARSCoV-2) [4, 5]. Indeed, the lack of such sensors explains why developing countries could not test their population to the extent recommended by the World Health Organization, which would have been essential for the monitoring to prevent the person-to-person transmission chain [6,7]. Mass testing has been almost entirely based on molecular techniques, especially real-time polymerase chain reaction (RT-PCR), which is not amenable to use outside specialized laboratories. At the research level, various methods have been used to diagnose SARS-CoV-2 infection via the detection of $\mathrm{S}$ or $\mathrm{N}$ proteins in different biological matrices [8-10]. A summary of the sensors developed in recent 
months is presented in the Supplementary Material (Section S1 and Table S2). Of particular relevance to our work are the electrochemical immunoassays. For example, carbon blackbased screen-printed electrodes (SPE) and magnetic beads (MBs) were used to immobilize antibodies and detect $\mathrm{S}$ and $\mathrm{N}$ proteins with limits of detection (LOD) of $19 \mathrm{ng} \mathrm{mL}^{-1}$ and $8 \mathrm{ng} \mathrm{mL}^{-1}$, respectively [8]. A working electrode (WE) coated with graphene oxide (GO) was modified with 8-hydroxyquinoline (8H), 1-ethyl-3-(3-dimethylamino-propyl)carbodiimide (EDC), and N-hydroxysuccinimide (NHS) coupled with gold nanostars (AuNS), generating an ultrasensitive sensor that could detect the trace of viruses in aquatic biological media [6].

Electrochemical sensors with a set of electrodes, viz. working (WE), reference (RE), and counter (CE) electrodes, allow for multi-target detection, simple arrays, portability, and fast responses, being ideal for applications in situ [2, 11, 12]. Analytes can be detected and quantified through redox reactions when binding occurs between the target and the biorecognition element [13], and, therefore, the sensing performance depends strongly on the WE material $[14,15]$. SPEs are suitable for mass production and miniaturization at low prices, being advantageous compared with typical solid electrodes [16-18]. They may be produced on almost any type of substrate, either rigid or flexible, and on stretchable surfaces, using different materials [19], including paper [20], ceramic [21], and polymers [22]. When used in conjunction with nanomaterials, SPEs may lead to highly sensitive electrochemical sensors [2,23]. In this context, electrodeposited gold on SPEs enhances electrochemical activity [24] owing to a facilitated electron transfer and catalytic activity for oxidation and reduction reactions $[2,23,25,26]$. Gold deposition as a film ensures high conductivity and large surface-area-to-volume ratios, and enables modification with biomolecules. The properties of the gold layer may be tuned by varying the deposition potential $\left(E_{\mathrm{d}}\right)$ and deposition time $\left(t_{\mathrm{d}}\right)$, thus permitting the optimization of sensing performance [24, 27, 28].

In this study, we developed an immunosensor based on gold-carbon composite material, which detected the S proteins of SARS-CoV and SARS-CoV-2 as a proof of concept. To the best of our knowledge, this is the first time a single biosensor is used to detect both pathogens.

\section{Materials and methods}

\section{Chemicals}

Hydrogen tetrachloroaurate (III), mercaptoacetic acid (MAA), EDC, NHS, bovine serum albumin (BSA), potassium hexacyanoferrate (II) trihydrate, potassium hexacyanoferrate (III), fluorescein 5(6)-isothiocyanate (FITC), and sulfuric acid $\left(\mathrm{H}_{2} \mathrm{SO}_{4}\right)$ were purchased from Sigma-Aldrich (USA). Carbon paste ink (ELETRODAG 423SS E\&C) was obtained from LOCTITE® (Germany), and $\mathrm{Ag} / \mathrm{AgCl}$ ink $(90,701)$ was acquired from TICON (Brazil). Anti-SARS-CoV S protein antibodies (40,150-D006) and SARS-CoV S protein $(40,150-\mathrm{V} 08 \mathrm{~B} 2)$ were purchased from Sino Biological (China), while SARS-CoV-2 glycoprotein S1 (ab273068) was obtained from Abcam (EUA). Polyethylene terephthalate (PET) sheets for electrode fabrication were obtained from local stationery shops and cleaned with isopropyl alcohol before use.

\section{Fabrication of screen-printed electrodes}

The screen-printing technique was used to produce carbon electrodes (Fig. 1a). First, a customized polyester screen (77 mesh) (Silk Center, Brazil) was designed using AutoCAD software and produced by Iasa Segmentos Industriais (Brazil). The carbon paste ink was then manually printed on a PET sheet with a polyurethane squeegee. The printed devices containing the three electrodes were then cured at $90{ }^{\circ} \mathrm{C}$ for $30 \mathrm{~min}$. The reference electrodes were manually painted with $\mathrm{Ag} / \mathrm{AgCl}$ ink and dried at $90{ }^{\circ} \mathrm{C}$ for $45 \mathrm{~min}$. An insulator adhesive tape was used to delimit the geometric area of the working electrode at $12.56 \mathrm{~mm}^{2}$.

\section{Electrodeposition of gold}

All electrodes received an electrochemical pretreatment with sulfuric acid $\left(0.5 \mathrm{~mol} \mathrm{~L}^{-1}\right)$ within a potential range between -2.5 and $+2.5 \mathrm{~V}$ at a scan rate of $100 \mathrm{mV} \mathrm{s}^{-1}$ [29]. Two voltammetry cycles were performed, and the sulfuric acid was completely replaced after each cycle. Gold nanoparticles were electrogenerated on screen-printed electrodes by applying a constant potential of $-4.0 \mathrm{~V}$ in an electrochemical cell containing $20 \mathrm{~mL} 5.0 \mathrm{mmol} \mathrm{L}^{-1}$ hydrogen tetrachloroaurate (III) solution with $0.5 \mathrm{~mol} \mathrm{~L}^{-1}$ sulfuric acid under vigorous stirring for $9 \mathrm{~s}$ (or $30 \mathrm{~s}$ or $90 \mathrm{~s}$ ) (Fig. 1b) [30].

\section{Optical characterization of the modified electrodes}

Images of the gold nanostructures were obtained with a scanning electron microscope (SEM) (ZEISS, LE0 440, model 7060) equipped with an OXFORD® system detector. A Thermo Scientific Prisma E Scanning Electron Microscope (SEM) with ColorSEM Technology and integrated energy-dispersive X-ray spectroscopy (EDS) was used to assess the chemical composition of the modified electrodes. The antigen-antibody interaction was studied using a confocal fluorescence microscope Zeiss LSM 780 with an argon laser. SARS-CoV 
(A)
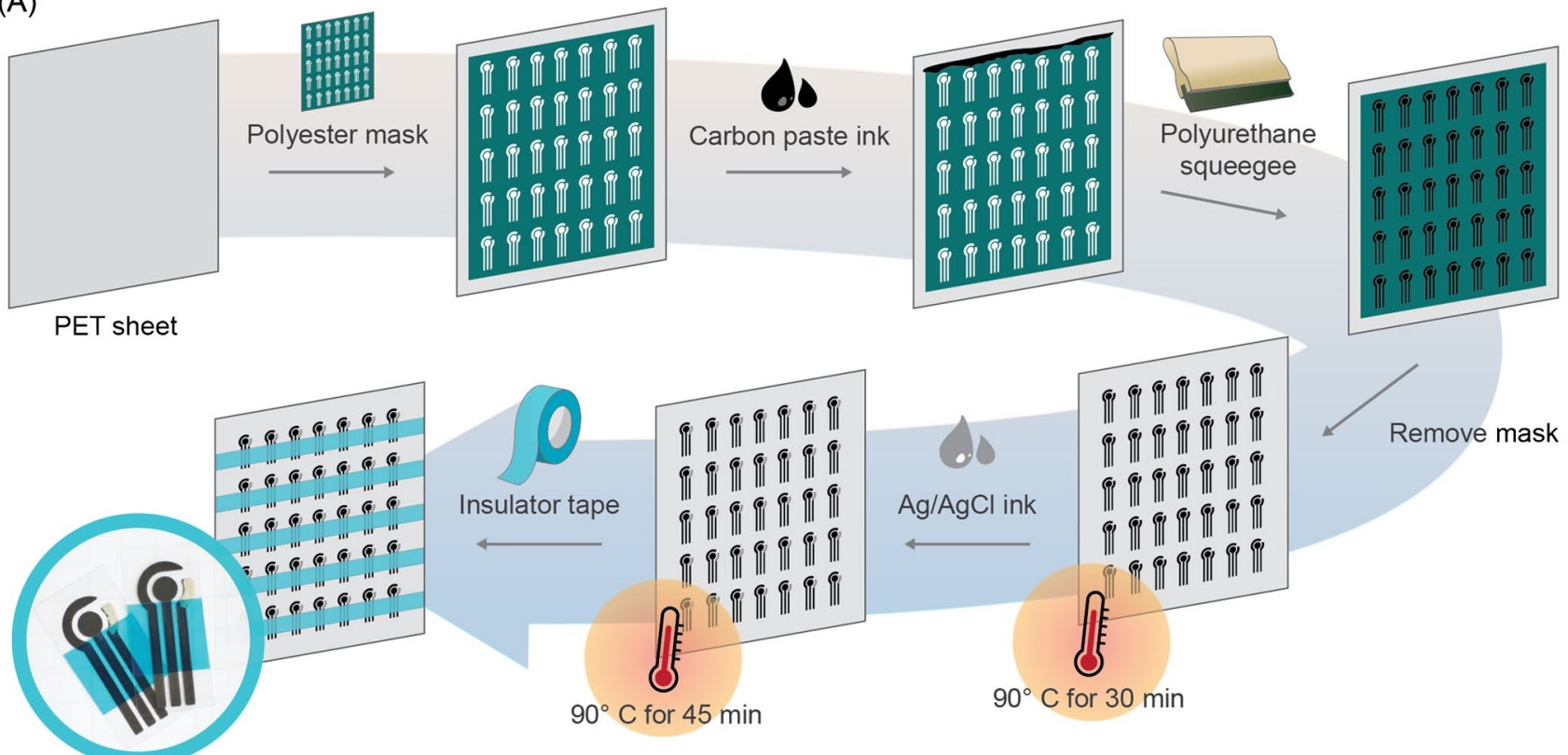

(B)

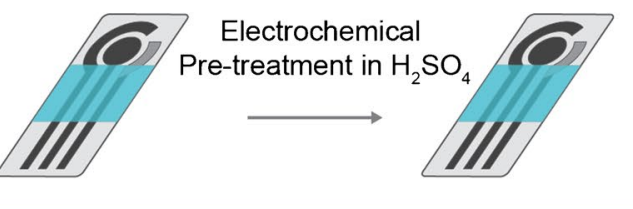

Electrochemical Deposition of $\mathrm{Au}$
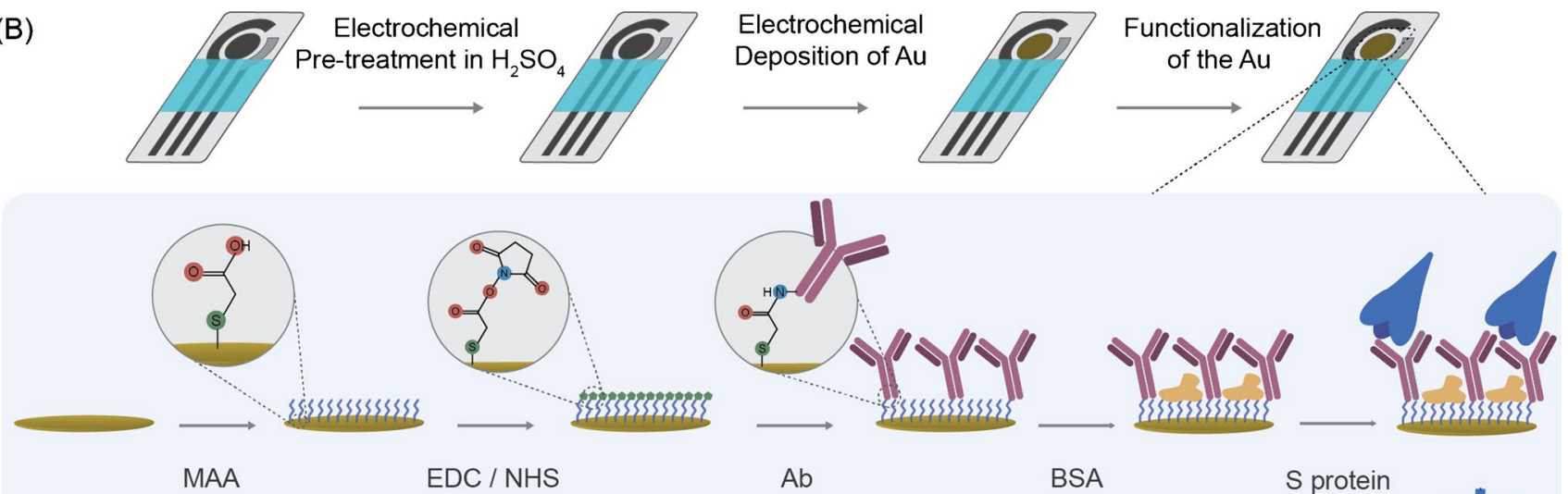

$\mathrm{Ab}$
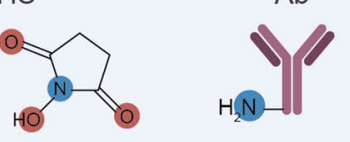

BSA

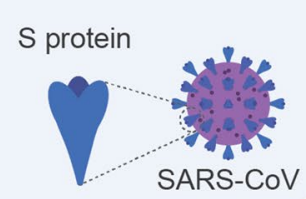

Fig. 1 Step-by-step immunosensor fabrication. a Fabrication steps of the screen-printed electrodes. b Electrochemical treatments, Au deposition, and modification of working electrodes with antibodies

$S$ protein was labeled with fluorescein isothiocyanate (FITC) by mixing the two molecules in a 1:20 ratio for $1 \mathrm{~h}$ at room temperature $\left(25^{\circ} \mathrm{C}\right)$. Dialysis was then used to remove unbound FITC. The fluorescence of the modified electrodes was measured in the absence and presence of labeled $\mathrm{S}$ proteins, validating its binding to the biosensor surface.

\section{Electrochemical characterization of the modified electrodes}

Modified electrodes using different gold electrodeposition conditions were characterized using cyclic voltammetry (CV). Bare carbon electrodes and devices submitted to 9, 30 , and $90 \mathrm{~s}$ of gold deposition protocol were evaluated. First, $\mathrm{CV}$ was performed in a potassium hexacyanoferrate (II)/(III) solution (4 mmol L-1 each, $0.1 \mathrm{~mol} \mathrm{~L}^{-1} \mathrm{PBS}, \mathrm{pH}$ 
7.0) ( 2 cycles, $100 \mathrm{mV} \mathrm{s}^{-1}$, from -0.3 to $\left.0.7 \mathrm{~V}\right)$. The electrodes were also submitted to $\mathrm{CV}$ in $0.1 \mathrm{~mol} \mathrm{~L}^{-1}$ sulfuric acid to assess the amount of gold present on the electrode ( 2 cycles, $100 \mathrm{mV} \mathrm{s}^{-1}$, from 0.0 to $1.5 \mathrm{~V}$ ).

\section{Functionalization of the gold surface with antibodies}

Modified-gold electrodes were pretreated with cyclic voltammetry (CV) $\left(0.0-1.5 \mathrm{~V}, 100 \mathrm{mV} \mathrm{s}^{-1}, 10\right.$ cycles) in sulfuric acid $\left(0.1 \mathrm{~mol} \mathrm{~L}^{-1}\right.$, ultrapure water). Then, $20 \mu \mathrm{L}$ of an MAA solution (10 $\mathrm{mmol} \mathrm{L}^{-1}$, ultrapure water) was incubated on the gold working electrode. After $2 \mathrm{~h}$, electrodes were washed with ultrapure water and dried using a low $\mathrm{N}_{2}$ stream. Next, $20 \mu \mathrm{L}$ of a mixture of EDC and NHS $(10 \mathrm{mmol}$ $\mathrm{L}^{-1}$ and $20 \mathrm{mmol} \mathrm{L}^{-1}$ respectively) in MES buffer $100 \mathrm{mmol}$ $\mathrm{L}^{-1}$ ( $\mathrm{pH}$ 6.0) was incubated on the modified electrode for $1 \mathrm{~h}$ to promote the antibody attachment on the carboxylic groups [12, 31-34]. The electrodes were then rinsed using MES buffer (100 mmol L ${ }^{-1}, \mathrm{pH}$ 6.0) and dried using $\mathrm{N}_{2}$. Twenty microliters of $1 \mu \mathrm{g} \mathrm{mL}{ }^{-1}$ anti-protein $\mathrm{S}$ antibodies (PBS, $0.1 \mathrm{~mol} \mathrm{~L}^{-1}, \mathrm{pH}$ 7.0) was added to the electrode for $1 \mathrm{~h}$. The antibody's concentration applied is within the concentration range reported in the literature for the manufacture of immunosensors used for SARS-CoV-2 detection, which range from $1 \mathrm{ng} \mathrm{L}^{-1}$ to $100 \mu \mathrm{g} \mathrm{L}^{-1}[31,32,35-40]$. Electrodes were washed using PBS (0.1 mol L $\left.{ }^{-1}, \mathrm{pH} 7.0\right)$ and dried with an $\mathrm{N}_{2}$ gas stream. Finally, a BSA solution ( $\left.1 \% \mathrm{w} / \mathrm{v}, 30 \mathrm{~min}, 0.1 \mathrm{~mol} \mathrm{~L}^{-1} \mathrm{PBS}, \mathrm{pH} 7.0\right)$ was incubated on the electrode for $30 \mathrm{~min}$ for blocking the bioreceptor layer [33, 35-37]. After washing the modified electrode with PBS $\left(0.1 \mathrm{~mol} \mathrm{~L}^{-1}, \mathrm{pH} 7.0\right)$ and drying it with $\mathrm{N}_{2}$, the biosensor was ready for use. A similar protocol for building the immunosensor was recently described by Stefano et al. [40]. The samples were added to the working electrode and incubated for $30 \mathrm{~min}\left(0.1 \mathrm{~mol} \mathrm{~L}^{-1} \mathrm{PBS}, \mathrm{pH} 7.0\right)$. After this period, electrodes were carefully washed using PBS $\left(0.1 \mathrm{~mol} \mathrm{~L}^{-1}\right.$, $\mathrm{pH}$ 7.0), and electrochemical measurements were performed (Fig. 1b). Unless indicated otherwise, positive samples were composed of SARS-CoV S protein, while negative samples were composed of BSA. To reduce the evaporation of the droplets, all the solutions for incubation were performed in a closed container with wet wipes. All procedures were performed at room temperature $\left(25^{\circ} \mathrm{C}\right)$.

\section{Electrochemical immunosensing}

The charge transfer resistance $\left(R_{\mathrm{ct}}\right)$ of the immunosensors was determined using electrochemical impedance spectroscopy (EIS) in a potassium hexacyanoferrate (II)/(III) solution (4 mmol L-1 each, $\left.0.1 \mathrm{~mol} \mathrm{~L}^{-1} \mathrm{PBS}, \mathrm{pH} 7.0\right)$. First, to activate the double layer of the biosensor, a $\mathrm{CV}$ was performed ( 2 cycles, from -0.3 to $0.7 \mathrm{~V}, 100 \mathrm{mV} \mathrm{s}^{-1}$ ). Then,
EIS measurements were performed in open circuit conditions (OCP) $\left(10 \mathrm{kHz}\right.$ to $\left.100 \mathrm{mHz}, \mathrm{E}_{\mathrm{ac}} 10 \mathrm{mV}\right)$. The reproducibility of the immunosensor was investigated by analyzing the signal of three parallel assemblies after the interaction with $10^{-9} \mathrm{~mol} \mathrm{~L}^{-1}$ protein $\mathrm{S}$. The variability is quantified in terms of relative standard deviation (RSD) in the signals. Repeatability was assessed using RSD of ten successive measurements in a single immunosensor after interaction with $10^{-9} \mathrm{~mol} \mathrm{~L}^{-1} \mathrm{~S}$ protein. The LOD was estimated as the analyte concentration corresponding to an $R_{\mathrm{ct}}=b_{m}+3 s_{b}$, where $b_{m}$ is the mean value for blank samples, and $s_{b}$ is the standard deviation of the blank measurements $(n=6)$ [41].

\section{Biological samples}

Saliva was used as a biological sample to test the practical application of the device. A pooled human saliva was obtained from Innovative Research (IRHUSL5ML) and centrifuged at $8000 \mathrm{rcf}$ for $10 \mathrm{~min}$ prior to use. Then, the supernatant was spiked with SARS-CoV S protein to reach concentrations from $10^{-11}$ to $10^{-7} \mathrm{~mol} \mathrm{~L}^{-1}$ and one sample was prepared with inactivated SARS-CoV-2 viruses at $10^{6}$ $\mathrm{PFU} \mathrm{mL}{ }^{-1}$. For the electrochemical analysis of fortified biological samples, SDS $0.05 \%$ (w/v in PBS) was used as the washing solution between incubations.

\section{Results and discussion}

\section{Characterization of Au-modified SPCEs}

The photographs of Au-modified SPEs in Fig. 2a indicate an increased deposition of $\mathrm{Au}$ as the electrodeposition time increases. The chemical composition of the films was confirmed through elemental mapping and EDS measurements in Fig. 2b, Figure S1, and Figure S2. While bare SPE has a carbon-based surface, Au features appear with increasing Au deposition. A homogeneous thin film was noted for bare SPE, coated with Au structures with regular size and morphology. Different Au structures are shown in the SEM images of Fig. 2c-f, with no significant defects for bare SPE and Au-coated SPEs. The bright spots on the images can be attributed to $\mathrm{Au}$, while other features in Fig. $2 \mathrm{c}$ are graphite flakes and carbon nanoparticles from SPE ink. According to ImageJ processing, the Au nanoparticles increased with electrodeposition time, reaching diameters $143 \pm 31,425 \pm 161$, and $752 \pm 207 \mathrm{~nm}(n=10)$, for 9,30 , and $90 \mathrm{~s}$, respectively. The $\mathrm{Au}$ deposition was characterized using cyclic voltammetry in $0.1 \mathrm{~mol} \mathrm{~L}^{-1}$ sulfuric acid. Figure $2 \mathrm{~g}$ shows no redox peaks for bare SPE (black), as expected. The CVs for SPE/ $\mathrm{Au}$ are typical of surfaces containing $\mathrm{Au}$ in $0.1 \mathrm{~mol} \mathrm{~L}^{-1}$ $\mathrm{H}_{2} \mathrm{SO}_{4}$, with anodic and cathodic peaks at $+1.15 \mathrm{~V}\left(E_{\mathrm{pa}}\right)$ and $+0.4 \mathrm{~V}\left(E_{\mathrm{pc}}\right)$ due to oxidation (formation) and reduction 

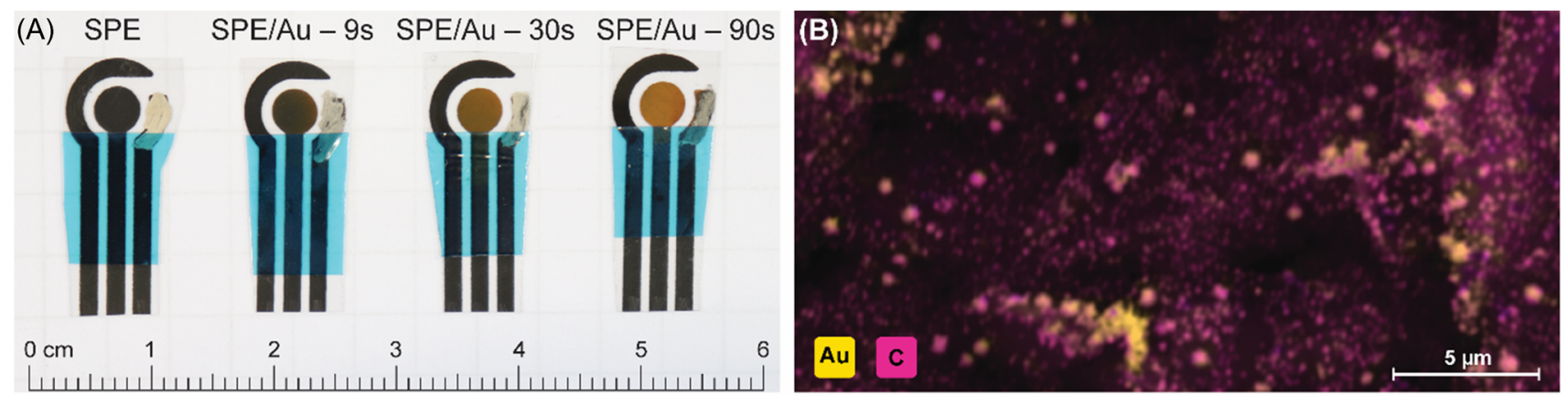

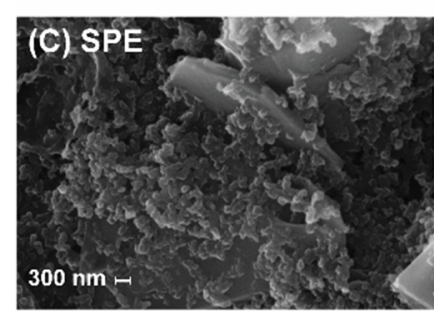

(G)

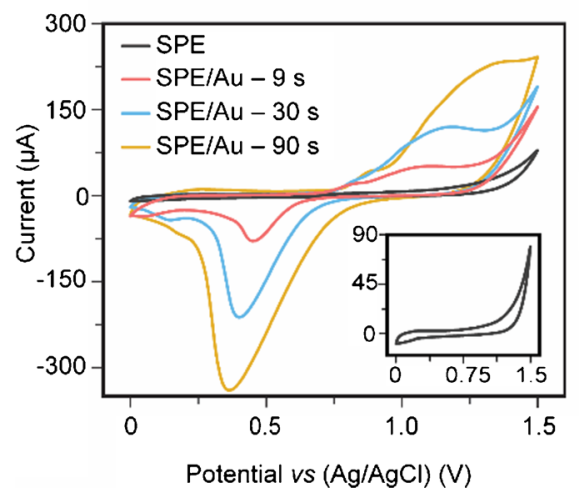

$(\mathrm{H})$

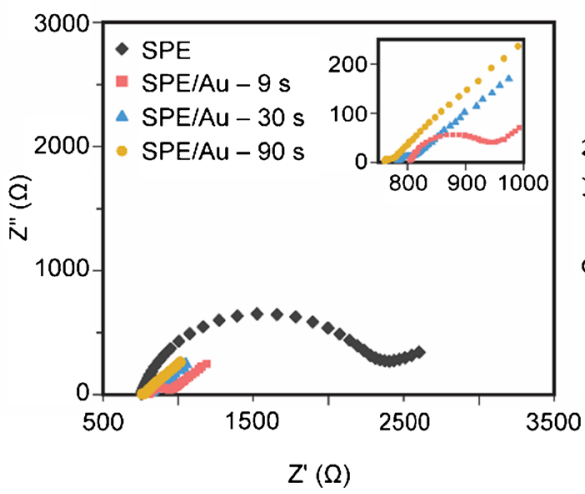

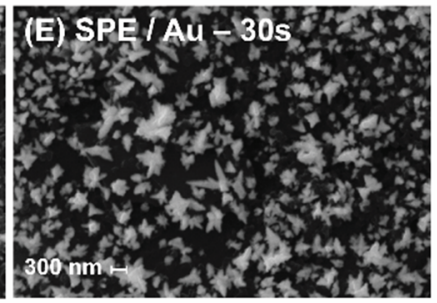

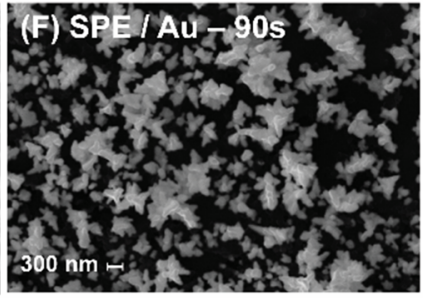

(I)

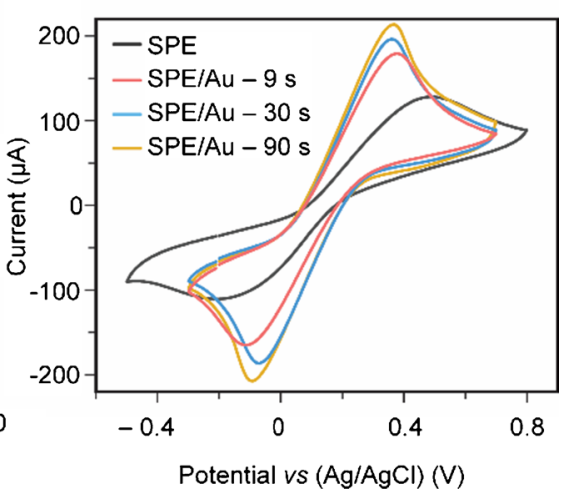

Fig. 2 a SPE before and after electrodeposition of gold for 9, 30, and $90 \mathrm{~s}$. b Elemental mapping of an SPE after electrodeposition of gold for $9 \mathrm{~s}$. Pink and yellow shades, respectively, represent carbon and gold. c Bare SPE. SPE modified with gold nanostructures electrodeposited during d $9 \mathrm{~s}$, e $30 \mathrm{~s}$, and f $90 \mathrm{~s}$. g Cyclic voltammograms in $0.1 \mathrm{~mol} \mathrm{~L}^{-1} \mathrm{H}_{2} \mathrm{SO}_{4}$ for bare SPE (black), SPE modified with gold nanostructures electrodeposited during $9 \mathrm{~s}$ (red), $30 \mathrm{~s}$ (blue), and $90 \mathrm{~s}$ (yellow) at $-4.0 \mathrm{~V}$ in a $5.0 \mathrm{mmol} \mathrm{\textrm {L } ^ { - 1 }}$ hydrogen tetrachloroaurate (III) solution containing $0.5 \mathrm{~mol} \mathrm{~L}^{-1}$ sulfuric acid. Scan rate $100 \mathrm{mV} \mathrm{s}^{-1}$.
The insert shows a zoomed view of the CV of SPE. h Nyquist plots for bare SPE (black), SPE modified with gold nanostructures electrodeposited during $9 \mathrm{~s}$ (red), $30 \mathrm{~s}$ (blue), and $90 \mathrm{~s}$ (yellow) in $0.1 \mathrm{~mol}$ $\mathrm{L}^{-1}$ PBS containing $4.0 \mathrm{mmol} \mathrm{L}^{-1}\left[\mathrm{Fe}(\mathrm{CN})_{6}\right]^{4-/ 3-}$ from $10 \mathrm{kHz}$ to $100 \mathrm{mHz}$. i CVs for bare SPE (black), SPE modified with gold microstructures electrodeposited during $9 \mathrm{~s}$ (red), $30 \mathrm{~s}$ (blue), and $90 \mathrm{~s}$ (yellow). CV conditions: $0.1 \mathrm{~mol} \mathrm{~L}{ }^{-1}$ PBS containing $4.0 \mathrm{mmol} \mathrm{L}^{-1}$ $\left[\mathrm{Fe}(\mathrm{CN})_{6}\right]^{4-13-}$ at a scan rate of $100 \mathrm{mV} \mathrm{s}^{-1}$.

AuNPs on the electrode leads to an increased reduction peak from $\mathrm{Au}^{+}$to $\mathrm{Au}^{0}$, corroborating the cyclic voltammograms in Fig. $2 \mathrm{~g}$.

The shape and morphology of the nanoparticles affect the electrochemical properties of modified electrodes, primarily due to the electroactive areas $[43,44]$. Thus, the electrodeposition time is a crucial factor, as observed in Fig. 2d-f, with peak current increasing with time due to increased surface area. Thicker films preclude electron transfer and induce a large capacitive current, while the small capacitance prevailing with thin films enhances sensitivity [24]. The importance of patterning SPE with Au structures became apparent in the increased electron transfer compared to bare SPE times already observed with SEM and EDS. The increase in 
electrodes, as inferred from CV and EIS measurements. Figure $2 \mathrm{~h}$ shows the Nyquist diagrams for the four electrodes consisting of semicircles and diffusion straight lines. These were analyzed using a modified Randles equivalent circuit $\left[\mathrm{R}_{\mathrm{s}}\left(\mathrm{CPE}\left[\mathrm{R}_{\mathrm{ct}} \mathrm{Z}_{\mathrm{W}}\right]\right)\right]$, where $R_{\mathrm{s}}$ is the solution resistance, $R_{\mathrm{ct}}$ is the charge transfer resistance, $Z_{\mathrm{W}}$ is the Warburg impedance, and CPE is a constant phase element. The apparent heterogeneous electron rate constant was determined using $k_{\text {app }}=R T / F^{2} R_{\mathrm{ct}} C A$, in which $F$ is the Faraday constant, $C$ is the probe redox concentration in solution $\left(4.0 \mathrm{mmol} \mathrm{L}^{-1}\right), R$ is the gas constant $\left(8.3145 \mathrm{~J} \mathrm{~K}^{-1} \mathrm{~mol}^{-1}\right), T$ is the temperature $(298 \mathrm{~K}), A$ is the geometric area $\left(0.1256 \mathrm{~cm}^{2}\right)$, and $R_{\mathrm{ct}}$ is the charge transfer resistance obtained by fitting the data. $k_{\text {app }}$ values calculated for bare SPE and SPE/Au are listed in Table S1. $R_{\mathrm{ct}}$ for SPE/Au $(<88 \Omega)$ is smaller than for bare SPE (1335 $\Omega$ ) due to the synergy in having SPE and Au sites for electron transfer. The significant increase in $k_{\text {app }}$ (from 15 to $5 \times 10^{4}$ times, depending on the gold amount) for the SPE/ Au electrode confirms the increased electron transfer during the redox process [45]. The same effect can be observed in the $\mathrm{CV}$ in $\left[\mathrm{Fe}(\mathrm{CN})_{6}\right]^{4-/ 3-}$ (Fig. 2i), in which the peak current of the oxidation/reduction of the redox pair increased with longer electrodeposition times. This observation has important implications for the performance of electroanalytical devices. The electrochemical behavior of gold-modified electrodes was also assessed in mechanical flexion tests. Even after 50 successive manual bending cycles, no significant changes in current or potential of $\left[\mathrm{Fe}(\mathrm{CN})_{6}\right]^{4-/ 3-}$ oxidation peaks were observed (deviations of $6.0 \%$ and $5.3 \%$ for current and potential, respectively, $n=3$ ) (Figure S4).

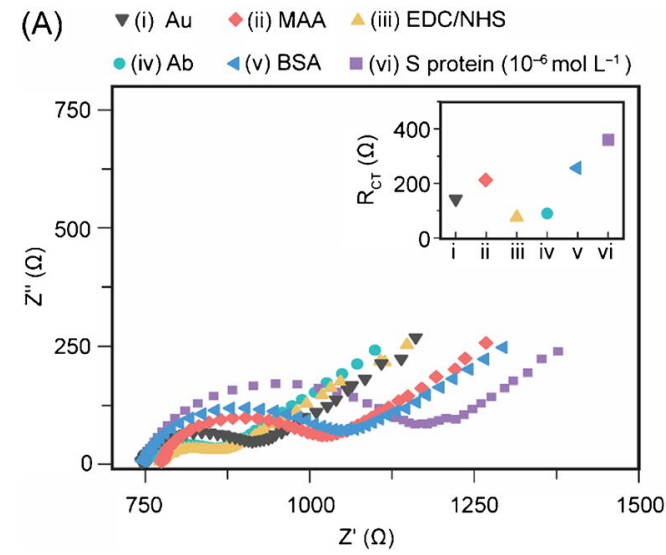

Fig. 3 a Nyquist plots in $0.1 \mathrm{~mol} \mathrm{~L}^{-1}$ phosphate buffer containing $5.0 \mathrm{mmol} \mathrm{L} \mathrm{L}^{-1}\left[\mathrm{Fe}(\mathrm{CN})_{6}\right]^{3-} /^{4-}$ using: (i) bare SPCE/AuNP (inverted triangle, black), (ii) SPCE/AuNP/MAA (diamond, red), (iii) SPCE/ AuNP/MAA/EDC-NHS (triangle, yellow), (iv) SPCE/AuNP/MAA/ EDC-NHS/antibody (circle, green), (v) SPCE/AuNP/MAA/EDCNHS/antibody/BSA (left-pointing triangle, blue), (vi) and SPCE/ AuNP/MAA/EDC-NHS/antibody/BSA/antigen (square, purple).

\section{Assembling the immunosensor}

An immunosensor was assembled with a modified SPE with a gold deposition time of $9 \mathrm{~s}$ and monitored through the Nyquist diagrams in Fig. 3a. The use of a 9-s deposition time is justified by the increased sensitivity of these devices, as shown in "Analytical performance of the immunosensor." The immobilization of MAA as a selfassembled monolayer (SAM) on the electrode caused $R_{\mathrm{ct}}$ to increase to $212.9 \Omega$ (curve: diamond, red) from 144.5 $\Omega$ for the bare electrode (curve: inverted triangle, black). A significant decrease to $76.8 \Omega$ occurred with the immobilization with EDC/NHS, probably due to the $\mathrm{pH}$ used in the reaction (6.0). Antibody immobilization on the SPCE/ AuNP/MAA/EDC-NHS surface increased $R_{\text {ct }}$ slightly to $92.4 \Omega$. With BSA immobilization for blocking active carboxylic acids, $R_{\mathrm{ct}}$ increased to $259.3 \Omega$. The incubation of $10^{-6} \mathrm{~mol} \mathrm{~L}^{-1}$ antigen (SARS-CoV S protein) on the SPCE/AuNP/MAA/EDC-NHS/Ab immunosensor led to a further increase in $R_{\mathrm{ct}}$ to $362.4 \Omega$ due to hindered electron mobility with the formation of the antigen-antibody complex. This complex represents an additional barrier between the electrode and $\left[\mathrm{Fe}(\mathrm{CN})_{6}\right]^{3-14-}$ redox probes. Similar behavior was observed by Brazaca et al. [34] and Huang and co-workers [46], who considered the results to indicate biosensor assembling, decreasing the chances of a false positive response during impedimetric assays. The antibody-antigen interaction was also investigated using confocal fluorescence microscopy. The images taken before and after the interaction between MAA/EDC-NHS/ $\mathrm{Ab}$ functionalized electrode and a fluorescein-labeled

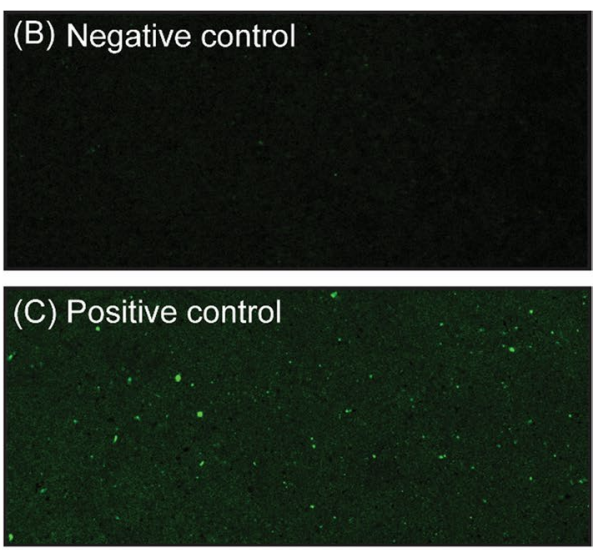

Conditions: 0.1-100,000 $\mathrm{Hz}$ frequency range with pulse amplitude $10 \mathrm{mV}$. Inset: equivalent circuit to fit the experimental data. The insert brings $R_{\mathrm{ct}}$ values $(\Omega)$ after each functionalization step calculated using $\left[\mathrm{R}_{\mathrm{s}}\left(\mathrm{CPE}\left[\mathrm{R}_{\mathrm{ct}} \mathrm{Z}_{\mathrm{W}}\right]\right)\right]$ as an equivalent circuit. Fluorescence images of b MAA/EDC-NHS/Ab functionalized electrode, and $\mathbf{c}$ functionalized electrode after detection of fluorescein-labeled protein S from SARS-CoV. Amplification $20 \times$ 
(A)

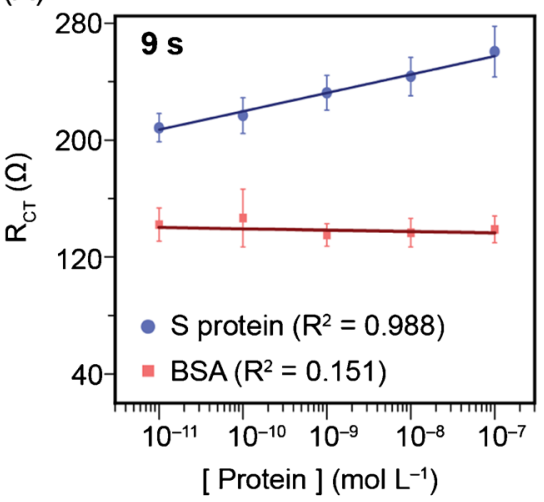

(D)

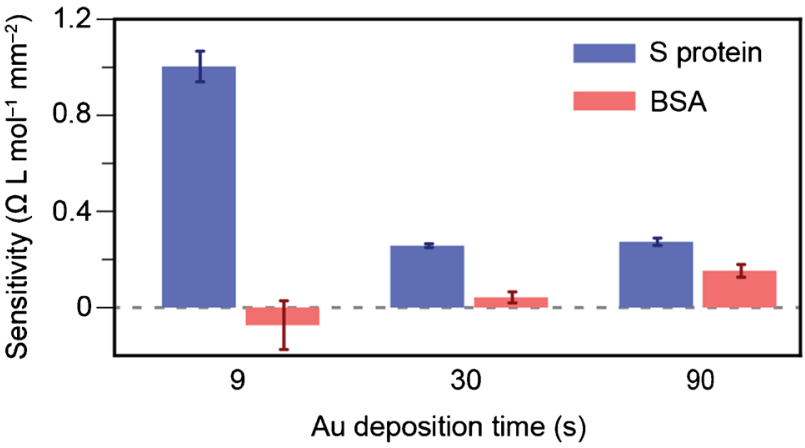

Fig. 4 Calibration curves of S protein and BSA for different Au deposition times: 9 (a), 30 (b), and $90 \mathrm{~s}$ (c). d Sensitivities for S protein and BSA for each Au deposition condition. EIS conditions: $0.1 \mathrm{~mol}$

SARS-CoV S protein in Fig. $3 b$ and c confirm the effective biological recognition.

\section{Analytical performance of the immunosensor}

Calibration curves obtained from $R_{\mathrm{ct}}$ for devices constructed with three gold electrodeposition times $(9,30$, and $90 \mathrm{~s})$ are shown in Fig. 4. All the immunosensors could differentiate SARS-CoV S protein from BSA, with $R^{2}$ and/or sensitivity values being significantly decreased for the BSA control assays. The highest sensitivity and selectivity were observed for the immunosensor containing fewer AuNPs (9 s electrodeposition), as indicated in Fig. 4D with $R^{2}=0.988$ and sensitivity $1.00 \Omega \mathrm{L} \mathrm{mol}^{-1} \mathrm{~mm}^{-2}$. With $9 \mathrm{~s}$ electrodeposition time, homogeneous spherical AuNPs are generated, thus confirming that the shape and morphology affect the electroanalytical performance [47]. For longer deposition times (30 and $90 \mathrm{~s}$ ) — or larger gold nanostructures - the sensitivity is lower $\left(0.258\right.$ and $0.274 \Omega \mathrm{L} \mathrm{mol}^{-1} \mathrm{~mm}^{-2}$ for 30 and $90 \mathrm{~s}$, respectively), with poor reproducibility $(>25 \%, n=3)$ which might be due to gold leaching. Although the longer deposition time led to increased electrochemical currents ("Characterization of Au-modified SPCEs"), electrodes with $9 \mathrm{~s}$ electrodeposition exhibited better analytical parameters for
(C)

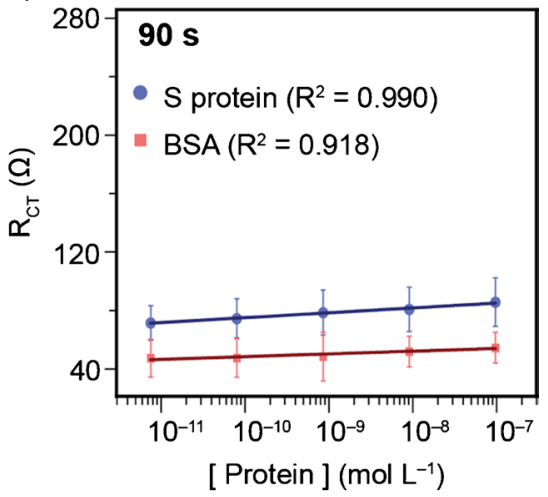

(E)

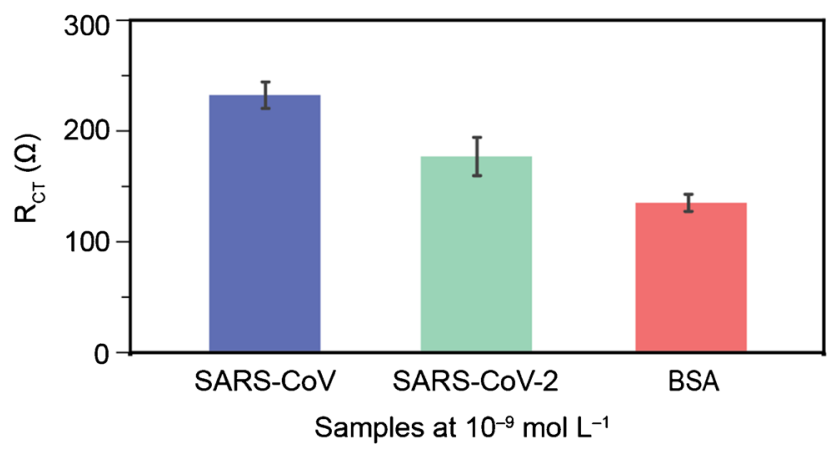

$\mathrm{L}^{-1}$ PBS containing $4.0 \mathrm{mmol} \mathrm{L}^{-1}\left[\mathrm{Fe}(\mathrm{CN})_{6}\right]^{4-/ 3-}$ at OCP. e $R_{\mathrm{ct}}$ signals from SARS-CoV, SARS-CoV-2, and BSA at $10^{-9} \mathrm{~mol} \mathrm{~L}^{-1}$ in PBS

detecting the S protein since the resistance to charge transfer was the parameter of interest rather than the electrochemical current. Furthermore, the cost of the sensing units is decreased with less gold being deposited, and therefore the $9 \mathrm{~s}$ electrodeposition time was used in subsequent studies.

All the sensing results reported so far were obtained with SARS-CoV protein as the target analyte. We now report on the use of the same immunosensor to detect SARS-CoV-2 S protein. Figure $4 \mathrm{e}$ shows that SPEs modified with $9 \mathrm{~s}$ gold deposition time could distinguish $10^{-9} \mathrm{~mol} \mathrm{~L}^{-1} \mathrm{~S}$ protein from SARS-CoV, S protein from SARS-CoV-2, and BSA (control) with a statistically significant difference using the ANOVA-Tukey test $(p \leq 0.05)$. To confirm this statistical significance, we plotted the data for BSA, SARS-CoV, and SARS-CoV-2 at the same concentration of $\mathrm{S}$ protein $\left(10^{-9} \mathrm{~mol} \mathrm{~L}^{-1}\right.$ in PBS) using principal component analysis (PCA). Figure S5 indicates excellent distinction of the samples, with more than $94 \%$ of data explained by PCA. We emphasize that all measurements were performed with the proteins separately and at the same concentration (BSA, SARS-CoV, and SARS-CoV-2).

As expected, $R_{\mathrm{ct}}$ after interaction with $\mathrm{S}$ protein from SARS-CoV-2 had an intermediate value due to its lower interaction rate with the antibodies than the $\mathrm{S}$ protein from 
SARS-CoV. $R_{\mathrm{ct}}$ differs in each case which means that the immunosensor platform may be used to differentiate SARS$\mathrm{CoV}$ viruses. The reason the immunosensor could be used to detect both S proteins, from SARS-CoV and SARS-CoV-2, is associated with their similar features. Indeed, SARS-CoV and SARS-CoV-2 are closely related, and their S proteins have an overall protein sequence identity of $76 \%$. The $\mathrm{S} 1$ receptor-binding domain is less conserved than the $\mathrm{S} 2$ fusion domain (76 and 90\% identity, respectively) [48]. According to the producer of anti-S protein antibodies used in this study, there is cross-reactivity with SARS-CoV-2 S protein [49]. The same was observed by Bates [50], who measured cross-reactivity for most SARS-CoV structural protein-targeted antibodies evaluated against SARS-CoV-2 S protein.

The reproducibility in device fabrication was tested with three immunosensors obtained with $9 \mathrm{~s}$ gold deposition, which were made to interact with $10^{-9} \mathrm{~mol} \mathrm{~L}^{-1} \mathrm{~S}$ protein. The immunosensor reproducibility was good, with an RSD of $5.12 \%(n=3)$. Although the immunosensor was designed to be disposable, the repeatability of the sensor was evaluated to ensure signal stability. This was done with ten successive measurements in a single device, and the response to $10^{-9} \mathrm{~mol} \mathrm{~L}^{-1}$ SARS-CoV S protein varied with a $4.51 \%$ RSD $(n=10)$. The LOD of the immunosensors was $3.16 \mathrm{pmol} \mathrm{L}^{-1}$ or $83.7 \mathrm{pg} \mathrm{mL}^{-1}$.

It is worth mentioning that the values used for quantifying $\mathrm{S}$ protein throughout this paper correspond to the total $R_{\mathrm{ct}}$ value from EIS measurements. Therefore, it corresponds to the biosensor itself (MAA, EDC/NHS, antibody, BSA blocking layer) plus the analyte. We have decided to use the total $R_{\mathrm{ct}}$ value instead of $\Delta R_{\mathrm{ct}}$ (before and after sample interaction) due to two main reasons. The first one is the simplification of the test for the user, requiring a single measurement. Furthermore, since using $\Delta R_{\mathrm{ct}}$ involves two measurements rather than one, the reproducibility of the tests may be affected [41]. Indeed, the RSD\% values $(n=3)$ for $R_{\mathrm{ct}}$ are $5.37 \%$ before and $5.12 \%$ after sample interaction, while RSD\% was $9.64 \%$ for the difference.

\section{Application of the immunosensor in biological samples}

Since saliva is a common means of transmission of infectious diseases [51], human saliva samples were applied to evaluate the analytical performance of the immunosensor produced with $9 \mathrm{~s}$ gold electrodeposition. As with other coronaviruses, the spike protein is abundantly expressed during virus infection and is most effective at inducing antibody responses in the host. Then, early diagnosis can be made by detecting antibodies against the SARS-CoV spike protein $[52,53]$. SARS-CoV S protein concentrations (from $10^{-11}$ to $10^{-7} \mathrm{~mol} \mathrm{~L}^{-1}$ ) were added to commercial human saliva supernatant obtained after centrifugation of the biological fluid. To assure that the changes in $R_{\mathrm{ct}}$ are due to antigen-antibody interactions, a control was conducted with saliva samples spiked with BSA in the same concentration range. To reduce nonspecific interactions between saliva components and the immunosensor, the latter was washed after sample incubation using PBS with the addition of a surfactant (SDS). Figure 5 shows the Nyquist plot (Fig. 5a) and the calibration curves (Fig. 5b) for human saliva spiked with SARS-CoV S protein (blue) and BSA (red). The curves are similar to those where PBS was used, with $R_{\mathrm{ct}}$ increasing linearly $\left(R^{2}=0.996\right)$ with the analyte addition (in log scale). As expected, a higher sensitivity was observed for $\mathrm{S}$ protein $\left(5.935 \Omega \mathrm{L} \mathrm{mol}^{-1} \mathrm{~mm}^{-2}\right)$ compared to BSA (1.725 $\Omega \mathrm{L} \mathrm{mol}^{-1} \mathrm{~mm}^{-2}$ ). However, $R_{\mathrm{ct}}$ is significantly higher than in the curves with PBS, probably due to nonspecific interactions with other saliva components. The increase of $R^{2}\left(R^{2}=0.929\right)$ and sensitivity related to BSA curves
(A)

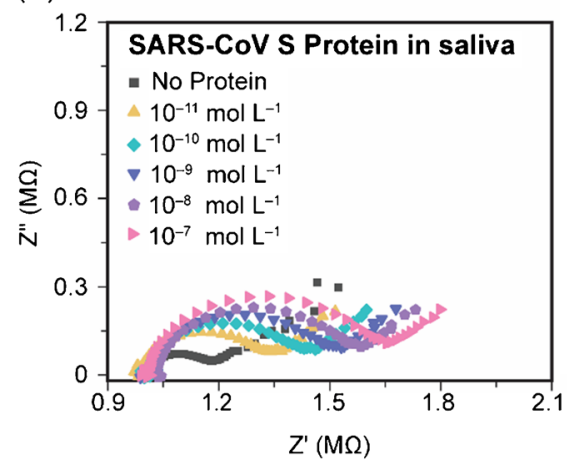

(B)

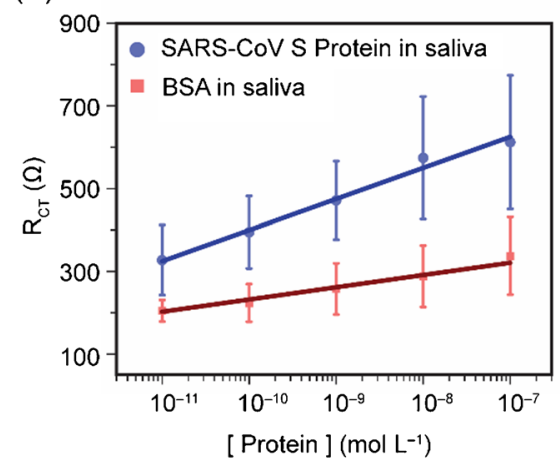

(C)

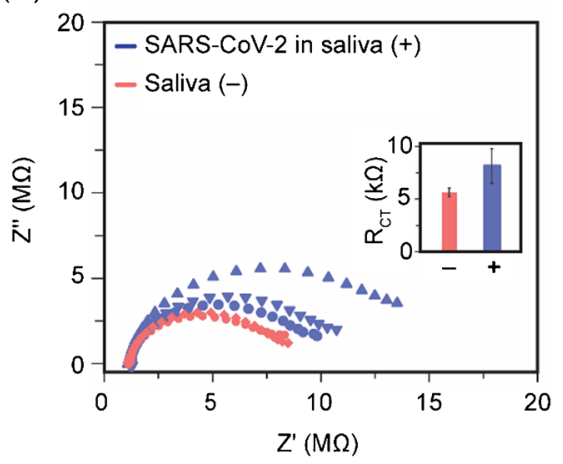

Fig. 5 Application of the proposed immunosensor in biological samples. a Nyquist plots after incubation of $\mathrm{S}$ protein from SARS-CoV from $10^{-11}$ to $10^{-7} \mathrm{~mol} \mathrm{~L}^{-1}$ in saliva samples. b Calibration curves for $\mathrm{S}$ protein from SARS-CoV and BSA in saliva. $\mathbf{c}$ Nyquist plot for detection of inactivated SARS-CoV-2 viruses in saliva. The inset shows the $R_{\mathrm{ct}}$ obtained for negative (in the absence of the virus) and

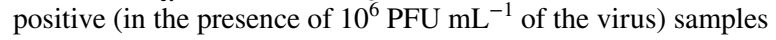


corroborates this hypothesis. This behavior is probably due to the successive incubations in saliva and not due to the concentration of BSA itself. Therefore, considering a single incubation (30 $\mathrm{min})$, the immunosensor can differentiate control and positive samples. It can distinguish $\mathrm{S}$ protein and BSA in concentrations ranging from $10^{-11}$ to $10^{-7} \mathrm{~mol}$ $\mathrm{L}^{-1}(n=3)$ even in a complex environment, indicating its potential applicability in biological samples.

Last, the biosensors were tested regarding their ability to detect inactivated SARS-CoV-2 viruses in saliva samples. As expected, the measured $R_{\mathrm{ct}}$ was significantly increased in the presence of the virus $\left(10^{6} \mathrm{PFU} \mathrm{mL} \mathrm{m}^{-1}\right)$ due to interaction with the immunosensor (Fig. 5c). As the typical range of positive cases of patients infected with SARS-CoV-2 is from $10^{5}$ to $10^{7} \mathrm{PFU} \mathrm{mL} \mathrm{m}^{-1}$, the proposed method exhibited excellent performance at a fortified sample at $10^{6} \mathrm{PFU}$ $\mathrm{mL}^{-1}$, showing potential applicability to clinical samples. It is also interesting to note that biosensors with similar or higher LODs than the one presented here were tested in real saliva clinical samples and showed great agreement with RT-PCR [8].

A list of immunosensing platforms for SARS-CoV and SARS-CoV-2 is shown in Tables $\mathrm{S} 2$ and S3, in the supplementary material. It is worth mentioning that none of the devices from the literature have been tested for the detection of both SARS-CoV and SARS-CoV-2, which is the case here. The immunosensor that we reported is competitive with other platforms. Even though its LOD is higher than more sophisticated immunosensors, its low cost (US\$ 0.03) and potential direct applicability to biological samples represent considerable advantages. The immunosensor is also advantageous due to the ease of preparation and manipulation, as it is label-free.

\section{Conclusions}

The fabrication of SPCEs decorated with electroformed gold nanoparticles was optimized and characterized. As a proof of concept, the electrodes were functionalized with a SAM and a layer of anti-S protein antibodies for a sensitive determination of S proteins from SARS-CoV and SARS-CoV-2. The label-free immunosensing platform had a LOD of $3.16 \mathrm{pmol}$ $\mathrm{L}^{-1}$ and provided quantitative results in fortified human saliva using only $10 \mu \mathrm{L}$ in a 30 min single incubation step. The high analytical performance exhibited by the disposable immunosensor and its simple operation-with no need for signal amplification strategies-make the method a potential alternative to identify SARS-CoV and SARS-CoV-2 in point-of-care settings. The immunosensor for $\mathrm{S}$ protein is competitive with other affinity electrochemical biosensors in terms of simplicity, test time, and sensitivity. Moreover, if necessary, the antibodies used in its construction can be updated to detect new variants of the disease. The features of the simple immunosensor are promising for the deployment of mass testing in any country. For the commercialization, efforts are still needed for a complete validation with a more significant number of samples and of different nature, in addition to a comparison with gold-standard techniques such as ELISA immunoassays and RT-PCR. Regardless, the goldbased immunosensor demonstrated good analytical performance and can be explored as an alternative for a faster and cheaper diagnosis of COVID-19.

Supplementary Information The online version contains supplementary material available at https://doi.org/10.1007/s00216-022-03956-1.

Acknowledgements The authors are grateful to Dr. Flavio Protásio Veras and Bruna Manuella Souza e Silva from the Center for Research in Inflammatory Diseases (FMRP/USP) for providing inactivated virus samples.

Funding The authors are grateful to São Paulo Research Foundation (FAPESP) (Grant \#2018/19750-3, 2016/01919-6, 2017/05362-9, 2018/22214-6, 2020/09587-8, 2017/21097-3, and 2019/01777-5); Conselho Nacional de Desenvolvimento Científico e Tecnológico (CNPq) (Grants 164569/2020-0, 303338/2019-9, and 423952/20188); and Coordenação de Aperfeiçoamento de Pessoal de Nível Superior - Brasil (CAPES) (Finance Code 001; grant \#3007/2014 - PROCAD; and Epidemias grant\# 88887.504861/2020-00) for financial support. We would like to thank the INCTBio grants (FAPESP \#2014/40867-3 and CNPq \#465389/2014-7, \#315824/2020-4).

Data availability The data associated with this manuscript is available and has been deposited in: Canniatti Brazaca, Lais; Imamura, Amanda Hikari; Oezau Gomes, Nathalia; Bortholazzi Almeida, Mariana; Tamara Scheidt, Desirée; Raymundo-Pereira, Paulo Augusto; Novais de Oliveira Jr, Osvaldo; Campos Janegitz, Bruno; Spinola Machado, Sergio Antonio; Carrilho, Emanuel (2021), "Electrochemical immunosensors using electrodeposited gold nanostructures for detecting the S proteins from SARS-CoV and SARS-CoV-2," Mendeley Data, V1, https://doi.org/10.17632/vzb9sn7cc2.1

\section{Declarations}

Conflict of interest The authors declare no competing interests.

\section{References}

1. Feng W, Newbigging AM, Le C, Pang B, Peng H, Cao Y, Wu J, Abbas G, Song J, Wang D-B, Cui M, Tao J, Tyrrell DL, Zhang X-E, Zhang H, Le XC. Molecular diagnosis of COVID-19: challenges and research needs. Anal Chem. 2020;92:10196-209. https://doi.org/10.1021/acs.analchem.0c02060.

2. Hernández-Rodríguez JF, Rojas D, Escarpa A. Electrochemical sensing directions for next-generation healthcare: trends, challenges, and frontiers. Anal Chem. 2021;93:167-83. https://doi. org/10.1021/acs.analchem.0c04378.

3. Raziq A, Kidakova A, Boroznjak R, Reut J, Öpik A, Syritski V. Development of a portable MIP-based electrochemical sensor for detection of SARS-CoV-2 antigen. Biosens Bioelectron. 2021;178:113029. https://doi.org/10.1016/j.bios.2021.113029. 
4. Brazaca LC, dos Santos PL, de Oliveira PR, Rocha DP, Stefano JS, Kalinke C, Abarza Muñoz RA, Bonacin JA, Janegitz BC, Carrilho E. Biosensing strategies for the electrochemical detection of viruses and viral diseases - a review. Anal Chim Acta. 2021;1159:338384. https://doi.org/10.1016/j.aca.2021.338384.

5. World Health Organization (2020) Coronavirus disease 2019 (COVID-19): situation report, 52. https://apps.who.int/iris/handle/10665/331476. Accessed 12 Mar 2021

6. Hashemi SA, GolabBehbahan NG, Bahrani S, Mousavi SM, Gholami A, Ramakrishna S, Firoozsani M, Moghadami M, Lankarani $\mathrm{KB}$, Omidifar N. Ultra-sensitive viral glycoprotein detection NanoSystem toward accurate tracing SARS-CoV-2 in biological/ non-biological media. Biosens Bioelectron. 2021;171:112731. https://doi.org/10.1016/j.bios.2020.112731.

7. Ji T, Liu Z, Wang G, Guo X, Akbar khan S, Lai C, Chen H, Huang S, Xia S, Chen B, Jia H, Chen Y, Zhou Q. Detection of COVID-19: a review of the current literature and future perspectives. Biosens Bioelectron. 2020;166:112455. https://doi.org/10. 1016/j.bios.2020.112455.

8. Fabiani L, Saroglia M, Galatà G, De Santis R, Fillo S, Luca V, Faggioni G, D'Amore N, Regalbuto E, Salvatori P, Terova G, Moscone D, Lista F, Arduini F. Magnetic beads combined with carbon black-based screen-printed electrodes for COVID19: a reliable and miniaturized electrochemical immunosensor for SARS-CoV-2 detection in saliva. Biosens Bioelectron. 2021;171:112686. https://doi.org/10.1016/j.bios.2020.112686.

9. Yakoh A, Pimpitak U, Rengpipat S, Hirankarn N, Chailapakul O, Chaiyo S. Paper-based electrochemical biosensor for diagnosing COVID-19: detection of SARS-CoV-2 antibodies and antigen. Biosens Bioelectron. 2021;176:112912. https://doi.org/10.1016/j. bios.2020.112912.

10. Seo G, Lee G, Kim MJ, Baek S-H, Choi M, Ku KB, Lee C-S, Jun S, Park D, Kim HG, Kim S-J, Lee J-O, Kim BT, Park EC, Il KS. Rapid detection of COVID-19 causative virus (SARS-CoV-2) in human nasopharyngeal swab specimens using field-effect transistor-based biosensor. ACS Nano. 2020;14:5135-42. https://doi.org/ 10.1021/acsnano.0c02823.

11. Alanazi K, Garcia Cruz A, Di Masi S, Voorhaar A, Ahmad OS, Cowen T, Piletska E, Langford N, Coats TJ, Sims MR, Piletsky SA. Disposable paracetamol sensor based on electroactive molecularly imprinted polymer nanoparticles for plasma monitoring. Sensors Actuators B Chem. 2021;329:129128. https://doi.org/10. 1016/j.snb.2020.129128.

12. Martins G, Gogola JL, Budni LH, Janegitz BC, Marcolino-Junior LH, Bergamini MF. 3D-printed electrode as a new platform for electrochemical immunosensors for virus detection. Anal Chim Acta. 2021;1147:30-7. https://doi.org/10.1016/j.aca.2020.12.014.

13. Cesewski E, Johnson BN. Electrochemical biosensors for pathogen detection. Biosens Bioelectron. 2020;159:112214. https://doi. org/10.1016/j.bios.2020.112214.

14. García-Miranda Ferrari A, Rowley-Neale SJ, Banks CE. Screenprinted electrodes: transitioning the laboratory in-to-the field. Talanta Open. 2021;3:100032. https://doi.org/10.1016/j.talo.2021. 100032.

15. Paschoalino WJ, Kogikoski S Jr, Barragan JTC, Giarola JF, Cantelli L, Rabelo TM, Pessanha TM, Kubota LT. Emerging considerations for the future development of electrochemical paper-based analytical devices. ChemElectroChem. 2019;6:10-30. https://doi. org/10.1002/celc.201800677.

16. Du CX, Han L, Dong SL, Li LH, Wei Y. A novel procedure for fabricating flexible screen-printed electrodes with improved electrochemical performance. IOP Conf Ser Mater Sci Eng. 2016;137:12060. https://doi.org/10.1088/1757-899x/137/1/ 012060 .

17. Dungchai W, Chailapakul O, Henry CS. Electrochemical detection for paper-based microfluidics. Anal Chem. 2009;81:5821-6.
18. Ibáñez-Redín G, Wilson D, Gonçalves D, Oliveira ON. Low-cost screen-printed electrodes based on electrochemically reduced graphene oxide-carbon black nanocomposites for dopamine, epinephrine and paracetamol detection. J Colloid Interface Sci. 2018;515:101-8. https://doi.org/10.1016/j.jcis.2017.12.085.

19. Wang S, Liu N, Yang C, Liu W, Su J, Li L, Yang C, Gao Y. Fully screen printed highly conductive electrodes on various flexible substrates for asymmetric supercapacitors. RSC Adv. 2015;5:85799-805. https://doi.org/10.1039/C5RA16724H.

20. Martins TS, Bott-Neto JL, Oliveira ON Jr, Machado SAS. Paperbased electrochemical sensors with reduced graphene nanoribbons for simultaneous detection of sulfamethoxazole and trimethoprim in water samples. J Electroanal Chem. 2021;882:114985. https:// doi.org/10.1016/j.jelechem.2021.114985.

21. Escamilla-Gómez V, Hernández-Santos D, González-García MB, Pingarrón-Carrazón JM, Costa-García A. Simultaneous detection of free and total prostate specific antigen on a screen-printed electrochemical dual sensor. Biosens Bioelectron. 2009;24:2678-83. https://doi.org/10.1016/j.bios.2009.01.043.

22. Narakathu BB, Devadas MS, Reddy ASG, Eshkeiti A, Moorthi A, Fernando IR, Miller BP, Ramakrishna G, Sinn E, Joyce M, Rebros M, Rebrosova E, Mezei G, Atashbar MZ. Novel fully screen printed flexible electrochemical sensor for the investigation of electron transfer between thiol functionalized viologen and gold clusters. Sensors Actuators B Chem. 2013;176:768-74. https://doi.org/10.1016/j.snb.2012.10.069.

23. Qian L, Durairaj S, Prins S, Chen A. Nanomaterial-based electrochemical sensors and biosensors for the detection of pharmaceutical compounds. Biosens Bioelectron. 2021;175:112836. https:// doi.org/10.1016/j.bios.2020.112836.

24. Kumar A, Gonçalves JM, Sukeri A, Araki K, Bertotti M. Correlating surface growth of nanoporous gold with electrodeposition parameters to optimize amperometric sensing of nitrite. Sensors Actuators B Chem. 2018;263:237-47. https://doi.org/10.1016/j. snb.2018.02.125.

25. Gupta P, Goyal RN, Shim Y-B. Simultaneous analysis of dopamine and 5-hydroxyindoleacetic acid at nanogold modified screen printed carbon electrodes. Sensors Actuators B Chem. 2015;213:72-81. https://doi.org/10.1016/j.snb.2015.02.066.

26. Satyanarayana M, Goud KY, Reddy KK, Gobi KV. Biopolymer stabilized nanogold particles on carbon nanotube support as sensing platform for electrochemical detection of 5-fluorouracil in-vitro. Electrochim Acta. 2015;178:608-16. https://doi.org/10. 1016/j.electacta.2015.08.036.

27. Cherevko S, Chung C-H. Direct electrodeposition of nanoporous gold with controlled multimodal pore size distribution. Electrochem Commun. 2011;13:16-9. https://doi.org/10.1016/j.elecom. 2010.11.001.

28. Kumar A, Furtado VL, Gonçalves JM, Bannitz-Fernandes R, Netto LES, Araki K, Bertotti M. Amperometric microsensor based on nanoporous gold for ascorbic acid detection in highly acidic biological extracts. Anal Chim Acta. 2020;1095:61-70. https:// doi.org/10.1016/j.aca.2019.10.022.

29. Raymundo-Pereira PA, Gomes NO, Machado SAS, Oliveira ON. Simultaneous, ultrasensitive detection of hydroquinone, paracetamol and estradiol for quality control of tap water with a simple electrochemical method. J Electroanal Chem. 2019;848:113319. https://doi.org/10.1016/j.jelechem.2019.113319.

30. Hernández-Saravia LP, Sukeri A, Bertotti M. Fabrication of nanoporous gold-islands via hydrogen bubble template: an efficient electrocatalyst for oxygen reduction and hydrogen evolution reactions. Int J Hydrogen Energy. 2019;44:15001-8. https://doi.org/ 10.1016/j.ijhydene.2019.04.186.

31. Soares JC, Soares AC, Angelim MKSC, Proença-Modena JL, Moraes-Vieira PM, Mattoso LHC, Oliveira ON Jr. Diagnostics of SARS-CoV-2 infection using electrical impedance spectroscopy 
with an immunosensor to detect the spike protein. Talanta. 2022;239:123076. https://doi.org/10.1016/j.talanta.2021.123076.

32. Zaccariotto GC, Silva MKL, Rocha GS, Cesarino I (2021) A novel method for the detection of SARS-CoV-2 based on grapheneimpedimetric immunosensor. Materials 14

33. Brazaca LC, Bramorski CB, Cancino-Bernardi J, da Silveira C-M, Markus RP, Janegitz BC, Zucolotto V. An antibody-based platform for melatonin quantification. Colloids Surfaces B Biointerfaces. 2018;171:94-100. https://doi.org/10.1016/j.colsurfb.2018. 07.006 .

34. Brazaca LC, Janegitz BC, Cancino-Bernardi J, Zucolotto V. Transmembrane protein-based electrochemical biosensor for adiponectin hormone quantification. ChemElectroChem. 2016;3:1006-11. https://doi.org/10.1002/celc.201600099.

35. Mehmandoust M, Gumus ZP, Soylak M, Erk N. Electrochemical immunosensor for rapid and highly sensitive detection of SARSCoV-2 antigen in the nasal sample. Talanta. 2022;240:123211. https://doi.org/10.1016/j.talanta.2022.123211.

36. Mojsoska B, Larsen S, Olsen DA, Madsen JS, Brandslund I, Alatraktchi FA (2021) Rapid SARS-CoV-2 detection using electrochemical immunosensor. Sensors 21

37. Zamzami MA, Rabbani G, Ahmad A, Basalah AA, Al-Sabban WH, Nate Ahn S, Choudhry H. Carbon nanotube field-effect transistor (CNT-FET)-based biosensor for rapid detection of SARSCoV-2 (COVID-19) surface spike protein S1. Bioelectrochemistry. 2022;143:107982. https://doi.org/10.1016/j.bioelechem.2021.107982.

38. Zhang M, Li X, Pan J, Zhang Y, Zhang L, Wang C, Yan X, Liu $\mathrm{X}, \mathrm{Lu}$ G. Ultrasensitive detection of SARS-CoV-2 spike protein in untreated saliva using SERS-based biosensor. Biosens Bioelectron. 2021;190:113421. https://doi.org/10.1016/j.bios.2021. 113421.

39. Zhao J, Fu Z, Li H, Xiong Y, Cai S, Wang C, Chen Y, Han N, Yang R. Magnet-assisted electrochemical immunosensor based on surface-clean Pd-Au nanosheets for sensitive detection of SARSCoV-2 spike protein. Electrochim Acta. 2022;404:139766. https:// doi.org/10.1016/j.electacta.2021.139766.

40. Stefano JS, Guterres e Silva LR, Rocha RG, Brazaca LC, Richter EM, Abarza Muñoz RA, Janegitz BC. New conductive filament ready-to-use for 3D-printing electrochemical (bio)sensors: towards the detection of SARS-CoV-2. Anal Chim Acta. 2022;1191:339372. https://doi.org/10.1016/j.aca.2021.339372.

41. Anderson DJ. Determination of the lower limit of detection. Clin Chem. 1989;35:2152-3. https://doi.org/10.1093/clinchem/35.10. 2152.

42. Raymundo-Pereira PA, Shimizu FM, Coelho D, Piazzeta MHO, Gobbi AL, Machado SAS, Oliveira ON. A nanostructured bifunctional platform for sensing of glucose biomarker in artificial saliva: synergy in hybrid Pt/Au surfaces. Biosens Bioelectron. 2016;86:369-76. https://doi.org/10.1016/j.bios.2016.06.053.

43. Carbone M, Nesticò A, Bellucci N, Micheli L, Palleschi G. Enhanced performances of sensors based on screen printed electrodes modified with nanosized $\mathrm{NiO}$ particles. Electrochim Acta. 2017;246:580-7. https://doi.org/10.1016/j.electacta.2017.06.074.
44. Karra S, Wooten M, Griffith W, Gorski W. Morphology of gold nanoparticles and electrocatalysis of glucose oxidation. Electrochim Acta. 2016;218:8-14. https://doi.org/10.1016/j.electacta. 2016.09.097.

45. Varodi C, Pogacean F, Coros M, Rosu M-C, Stefan-van Staden R-I, Gal E, Tudoran L-B, Pruneanu S, Mirel S (2019) Detection of 8-hydroxy-2'-deoxyguanosine biomarker with a screen-printed electrode modified with graphene. Sensors 19

46. Huang M, Li H, He H, Zhang X, Wang S. An electrochemical impedance sensor for simple and specific recognition of G-G mismatches in DNA. Anal Methods. 2016;8:7413-9. https://doi.org/ 10.1039/C6AY01705C.

47. Xu J, Zhao S, Teng T, Abdalla AE, Zhu W, Xie L, Wang Y, Guo $\mathrm{X}$. Systematic comparison of two animal-to-human transmitted human coronaviruses: SARS-CoV-2 and SARS-CoV. Viruses. 2020;12:244.

48. Jaimes JA, André NM, Chappie JS, Millet JK, Whittaker GR. Phylogenetic analysis and structural modeling of SARS-CoV-2 spike protein reveals an evolutionary distinct and proteolytically sensitive activation loop. J Mol Biol. 2020;432:3309-25. https:// doi.org/10.1016/j.jmb.2020.04.009.

49. Sino Biological (2021) SARS-CoV/SARS-CoV-2 spike antibody, chimeric MAb. https://www.sinobiological.com/antibodies/covspike-40150-d006. Accessed 17 May 2021

50. Bates TA, Weinstein JB, Farley S, Leier HC, Messer WB, Tafesse FG. Cross-reactivity of SARS-CoV structural protein antibodies against SARS-CoV-2. Cell Rep. 2021;34. https://doi.org/10. 1016/j.celrep.2021.108737.

51. Dave PK, Rojas-Cessa R, Dong Z, Umpaichitra V (2021) Survey of saliva components and virus sensors for prevention of COVID19 and infectious diseases. Biosensors 11

52. Chang M-S, Lu Y-T, Ho S-T, Wu C-C, Wei T-Y, Chen C-J, Hsu Y-T, Chu P-C, Chen C-H, Chu J-M, Jan Y-L, Hung C-C, Fan C-C, Yang Y-C. Antibody detection of SARS-CoV spike and nucleocapsid protein. Biochem Biophys Res Commun. 2004;314:9316. https://doi.org/10.1016/j.bbrc.2003.12.195.

53. Haynes LM, Miao C, Harcourt JL, Montgomery JM, Le MQ, Dryga SA, Kamrud KI, Rivers B, Babcock GJ, Oliver JB, Comer JA, Reynolds M, Uyeki TM, Bausch D, Ksiazek T, Thomas W, Alterson H, Smith J, Ambrosino DM, Anderson LJ. Recombinant protein-based assays for detection of antibodies to severe acute respiratory syndrome coronavirus spike and nucleocapsid proteins. Clin Vaccine Immunol. 2007;14:331-3. https://doi.org/10. 1128/CVI.00351-06.

Publisher's note Springer Nature remains neutral with regard to jurisdictional claims in published maps and institutional affiliations. 